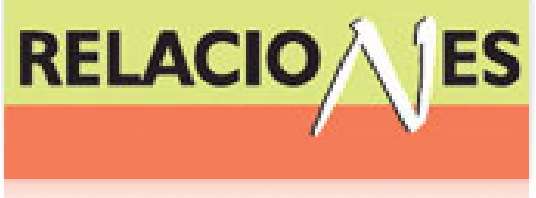

Relaciones. Estudios de historia y sociedad ISSN: 0185-3929

relacion@colmich.edu.mx

El Colegio de Michoacán, A.C

México

Vázquez Semadeni, María Eugenia

La imagen pública de la masonería en Nueva España, 1761-1821

Relaciones. Estudios de historia y sociedad, vol. XXXII, núm. 125, 2011, pp. 167-207

El Colegio de Michoacán, A.C

Zamora, México

Disponible en: http://www.redalyc.org/articulo.oa?id=13718526007

Cómo citar el artículo

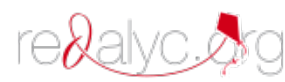

- Número completo

- Más información del artículo

Página de la revista en redalyc.org

Sistema de Información Científica

Red de Revistas Científicas de América Latina, el Caribe, España y Portugal Proyecto académico sin fines de lucro, desarrollado bajo la iniciativa de acceso abierto 


\title{
La imagen pública de la masonería en Nueva España, 1761-1821
}

\author{
María Eugenia Vázquez Semadeni* \\ UNIVERSITY OF CALIFORNIA, LOS ÁNGELES
}

En este artículo, desde la perspectiva del análisis de los lenguajes políticos, se revisa la imagen pública de la masonería que se desarrolló en Europa, durante el siglo xviIı y los primeros años del xix, y cómo llegó a Nueva España. Se muestra que algunos elementos de esa imagen se fueron privilegiando sobre otros, en función de las circunstancias políticas europeas y novohispanas. También se analiza cómo, más tarde, estos planteamientos se relacionaron con la pérdida del fundamento trascendental de legitimidad derivado de la crisis de la monarquía espańola, con la lucha por la independencia, con las resistencias contra ésta y con los procesos gaditanos. La investigación muestra que las interpretaciones sobre la masonería que se plasmaron en los textos revisados, y la forma en que eran expresadas, fueron resultado del momento histórico concreto que se estaba viviendo, por lo que sólo pudieron ser dichas de esa manera en un contexto -histórico y lingüístico- determinado; de modo que son hechos históricos en sí mismos, y forman parte de otros procesos mayores, en los que el debate público comenzaba a consolidarse como uno de los principales fundamentos de legitimidad.

(Masonería, debate público, lenguajes políticos, cultura política, legitimidad, independencia)

*maryuvas@gmail.com y maruvas@ucla.edu El presente artículo forma parte de la tesis titulada La interacción entre el debate público sobre la masonería y la cultura política, 17611830, que realicé para obtener el grado de doctora en Historia en El Colegio de Michoacán. Una primera versión de este trabajo se leyó como ponencia en el I Simposio Internacional de Historia de la Masonería Latinoamericana y Caribeña, Casa de Altos Estudios Don Fernando Ortiz/Universidad de La Habana, La Habana, Cuba, 5 al 8 de diciembre de 2007. Su revisión y corrección para este artículo fue posible gracias a la beca posdoctoral que me otorgó la Coordinación de Humanidades de la UnAM, en el marco del programa Becas Posdoctorales en la unAM. Agradezco profundamente los atinados comentarios de los miembros del seminario Proindependencia, en particular la atenta lectura de Gabriel Torres Puga. 


\section{INTRODUCCIÓN}

$\mathrm{M}$

uchos autores consideran que el pensamiento político fue la causa principal del proceso de independencia novohispano. Las interpretaciones tradicionales, derivadas del liberalismo decimonónico, sostenían que el movimiento de emancipación había sido resultado de los postulados de la Ilustración, del liberalismo y de la filosofía revolucionaria francesa. ${ }^{1}$ En esa misma tónica, varios autores señalaban que la masonería había sido un motor ideológico de la independencia, pues -como procuraré mostrar en este artículo- en los discursos del siglo xviıI y las primeras décadas del XIx la fraternidad masónica aparecía directamente vinculada con ese pensamiento dieciochesco que habría alimentado el ideario de la emancipación. ${ }^{2}$

Hace ya varias décadas que diversos autores han cuestionado la versión liberal sobre la emancipación y han planteado nuevas propuestas de interpretación. Trabajos como los de Luis Villoro, Carlos Herrejón, Hugh Hamill, David Brading, Jaime del Arenal, Rafael Rojas y Alfredo Ávila, ${ }^{3}$ entre otros, han mostrado que la lucha por la

${ }^{1}$ Alfredo Ávila, "Interpretaciones recientes en la historia del pensamiento de la emancipación” en Alfredo Avila y Virginia Guedea , coords., La independencia de México, temas e interpretaciones recientes, México, UNAM/IIH, 2007, 17.

${ }^{2}$ Las obras que abordan el tema son muy numerosas, por lo que las siguientes se indican únicamente como referencias principales de la postura mencionada: José María Mateos, Historia de la masonería en México, México, Herbasa, 2003; Luis J. Zalce y Rodríguez, Apuntes para la historia de la masonería en México, México, Herbasa, 1950; Ramón Martínez Zaldúa, Historia de la masonería en Hispanoamérica, México, Costaamic, 1967; Nicolás Rangel, La vida colonial. Los precursores ideológicos de la guerra de independencia. La masonería en México, siglo XVIII, Publicaciones del Archivo General de la Nación xxi, México, Talleres Gráficos de la Nación, 1932; María Teresa Berruezo, "La propaganda independentista de la logia mirandina en Londres", en José A. Ferrer Benimeli, coord., Masonería Española y América, Zaragoza, Centro de Estudios Históricos de la Masonería Española, 1993, 95-113; Guadalupe Jiménez Codinach, La Gran Bretaña y la independencia de México, 1808-1821, México, FCE, 1991; Sara A. Frahm, "La cruz y el compás: compromiso y conflicto", Secuencia, núm. 22, enero-abril 1992, 67-102.

${ }^{3}$ Luis Villoro, El proceso ideológico de la revolución de independencia, México, CONACuLTA, 1992; "La revolución de Independencia, en Historia General de México, México, El Colegio de México, 2000, 491-523, y "Rousseau en la Independencia mexicana”, Revista Casa del Tiempo, núm. 80, septiembre 2005. Carlos Herrejón Peredo, Hidalgo. 
independencia no siempre estuvo fundada en los mismos ideales, que no todos los que participaron en ella sostenían los mismos principios, y que sus raíces ideológicas debían más a la tradición católica, al saber jurídico y al constitucionalismo histórico que al enciclopedismo o a Rousseau. ${ }^{4}$ Sin embargo, las preguntas que actualmente se le hacen al pensamiento de la emancipación no han alcanzado al tema masónico, que por lo mismo sigue subordinado a las interpretaciones tradicionales sobre el periodo.

La intención de este artículo entonces es preguntarse cuál fue la imagen pública de la masonería que circuló en Nueva España durante la segunda mitad del siglo XVIII, y cómo se expresaron y se posicionaron frente a ella los distintos grupos políticos de las primeras décadas del siglo xIx. El objetivo de este texto no es hacer historia de la masonería; no se pretende inquirir si los masones participaron en la contienda independentista, si trataron de difundir un ideario político o si la organización masónica proporcionó un espacio para la conspiración o la acción a favor de la separación de la metrópoli. La finalidad es revisar el pensamiento político del periodo a través de las ideas que se expresaban en el debate público sobre un tema específico: la masonería. Esto porque en la presente investigación se considera que los lenguajes políticos con los que actuaban y escribían los actores políticos y los publicistas del periodo se puede observar

Razones de la insurgencia y biografía documental, México, SEP, 1987 y "La revolución francesa en sermones y otros testimonios de México 1791-1823”, en Solange Alberro, Alicia Hernández Chávez y Elías Trabulse, coords., La revolución francesa en México, México, El Colegio de México, Centro de Estudios Mexicanos y Centroamericanos, 1992. Hugh M. Hamill Jr., The Hidalgo Revolt. Prelude to Mexican Independence, Gainesville, University of Florida Press, 1996. David A. Brading, Church and State in Bourbon Mexico. The diocese of Michoacán 1749-1810, Cambridge, Cambridge University Press, 1994. Jaime del Arenal Fenochio, "Modernidad, mito y religiosidad en el nacimiento de México" en Jaime E. Rodríguez, The Independence of Mexico and the Creation of the New Nation, Los Ángeles, University of California, Latin American Center Publicatiosn/México, Chicano Program, 1989, 237-246. Rafael Rojas, La escritura de la Independencia. El surgimiento de la opinión pública en México, México, Taurus, CIDE, 2003. Alfredo Ávila, "Cuando se canonizó la rebelión. Conservadores y serviles en Nueva España”, en Érika Pani, coord., Historia, conservadurismos y derechas en México, México, FCE, en prensa.

${ }^{4}$ Alfredo Ávila, "Interpretaciones recientes..., 2007, passim. 
con claridad en la forma en que se expresaban acerca de la masonería; en sus textos sobre el tema pueden apreciarse algunos de los principios y valores que sostenían, la manera en que fundamentaban sus demandas políticas, cómo las elaboraban y los medios con que ponían sus ideas en acción.

Dado que las preguntas que aquí se pretende responder se encuentran en el ámbito del debate público, las fuentes con que se trabaja primariamente son los impresos, los papeles públicos, que incluyen libros, folletos, manifiestos y publicaciones periódicas. Se otorgó particular importancia a las obras sobre la masonería escritas por autores europeos, que tuvieron cierta circulación en Nueva España, pues ellas alimentaron, en gran medida, la imagen pública que se fue elaborando de esa fraternidad. Se consultaron también las prohibiciones reales y eclesiásticas contra la masonería, así como los procesos contra masones - o supuestos masones-que se siguieron en la Inquisición novohispana y en la Sala del Crimen, pues en ellos es posible detectar las ideas sobre dicha asociación que privaban entre las autoridades, antes de y durante la contienda independentista.

Antes de proceder, cabe hacer una última precisión. Aunque aquí se habla de imagen pública de la masonería, parece claro que las ideas que conformaban dicha imagen eran dominio de un sector reducido de la población. Sólo aquellos pocos que tenían conocimiento de la existencia de la orden masónica fueron desarrollando una concepción sobre ella, y en un primer momento esa impresión se emitía sólo en espacios restringidos, como la Inquisición o las pequeñas reuniones en lugares semipúblicos. Poco a poco, esas ideas fueron llegando a periódicos y otro tipo de impresos, y con ello a una parte más amplia de la sociedad novohispana. En este trabajo se considera que esa imagen era pública por varias razones: una, porque los postulados antimasónicos que sustentaban las prohibiciones reales y eclesiásticas se hacían llegar, por diversas vías, a sectores más amplios de la población; dos, porque las ideas sobre la masonería circulaban en textos impresos, dirigidos a un público lector, que aún no se definía con claridad pero que estaba implícito en las obras que abordaban el tema; y tres, porque el que dichas ideas se discutieran en papeles públicos implicaba el reconocimiento de un nuevo espa- 
cio de legitimidad, que precisamente se estaba conformando en el periodo estudiado, y que se convirtió en un elemento fundamental de la nueva cultura política: el debate público.

\section{La ANTimasonería llega a Nueva España}

Cuando a principios del siglo XVIII la masonería especulativa ${ }^{5}$ se estableció en Gran Bretańa y comenzó a extenderse por Europa, fue adquiriendo una serie de características que la distinguieron de otras sociabilidades de la época y que generaron inquietud entre las autoridades civiles y eclesiásticas europeas. Las principales de esas características fueron: a) la existencia de prácticas secretas y el juramento de guardar ese secreto; b) su heterogénea composición social; c) la convivencia de hombres de diversos credos, d) el influjo que comenzó a tener en la opinión pública; y e) los rituales que -según la Iglesia- "afectaban la pureza de la religión" al mezclar elementos sagrados y profanos. ${ }^{6}$

A causa de las sospechas y temores que por esas causas despertaba, a partir de 1735 comenzaron a aparecer varios decretos monárquicos y bulas papales en contra de la francmasonería, cuyos tópicos principales eran muy semejantes: que podía afectar la seguridad de los Estados, al ser un posible foco de subversión; que se arrogaba prerrogativas que no le correspondían y que no le habían sido otorgadas por ninguna autoridad legítima, como el dictar sus propias leyes o el aplicar justicia; que afectaba la pureza de la religión católica; y que sus fines no podían ser buenos si actuaba en secreto. ${ }^{7}$

${ }^{5}$ La masonería especulativa es aquella que surgió a mediados del siglo xvir cuando los gremios de constructores medievales (masonería operativa) dejaron de centrarse en el arte de la construcción y se dedicaron a la búsqueda del saber filosófico, es decir, a lo que los masones llaman "arquitectura moral".

${ }^{6}$ José Antonio Ferrer Benimeli, La masonería española en el siglo XVIII, España, Siglo XXI de España, 1986. Bula del soberano pontifice contra los fracmazones, México, Imprenta Americana de D. José María Betancourt, 1822, 2. Proceso del francmasón Pedro Tournon, juzgado por la Inquisición de Madrid, el año de 1757, México, Imprenta en la oficina de D. J. M. B. y socios, 1822, 7.

${ }^{7}$ Algunos ejemplos de estas prohibiciones son la bula In Eminenti, de Clemente XII, de 1738; la bula Providas Romanorum, de Benedicto XIV, de 1751 y los decretos de Carlos VII de Nápoles y del monarca espańol Fernando VI, ambos también de 1751. 
Fue con base en dichas prohibiciones monárquicas y eclesiásticas que se formularon las principales argumentaciones que se desarrollarían en Europa, a lo largo del siglo XviII y las primeras décadas del XIX, en contra de la asociación masónica. Esos planteamientos se vieron complementados con una serie de ideas, derivadas de las suposiciones y sospechas que despertaba el desconocimiento de qué era la masonería, las cuales dieron lugar a muchos de los mitos sobre ella, algunos de los cuales persisten hasta la actualidad. Un ejemplo al respecto son los elementos con los que el padre Rávago, confesor de Fernando VI, intentó convencerlo de que dictara una prohibición contra la francmasonería. Rávago aseguraba que la existencia de una asociación como esa implicaba un gran peligro, y para demostrarlo se preguntaba lo que pasaría si la fraternidad se integrara de nobles y militares y fuera dirigida por el ambicioso rey de Prusia (Federico II, "El Grande"), quien formaría con la masonería un ejército invencible para gobernar toda Europa ${ }^{8}$ En estas aseveraciones se encuentra, sin duda, el germen de la teoría del complot, y de los mitos que consideran a la masonería una organización supranacional que pretende dominar el mundo.

Pronto las condenas de que era objeto generaron reacciones entre sus partidarios, lo cual dio lugar al surgimiento de una serie de obras apologéticas de la masonería, que defendían sus fines y principios al tiempo que cuestionaban la pertinencia y justicia de las prohibiciones. ${ }^{9}$ También se publicaron algunos textos que, aunque aceptaban y respetaban las posturas monárquica y papal, expresaban dudas acerca de las ideas negativas que se habían ido desarrollando sobre los francmasones y cuestionaban los fundamentos de las condenas. ${ }^{10}$ Desde luego, también aparecieron obras que intentaron explicar y apoyar el rechazo a la masonería, así como prevenir a los lectores para que se alejaran de ella. ${ }^{11}$

\footnotetext{
${ }^{8}$ Ferrer Benimeli, La masonería española en el siglo..., 1986, 153-159.

${ }^{9}$ Ejemplos de estas obras son Relation apologique et historique de la Société des FrancsMaçons (Dublín, 1738) y Apologie pour l'Ordre des Francsmaçons (La Haya, 1742), entre muchas más. Véase Ferrer Benimeli, Bibliografia de la masonería, Madrid, Fundación Universitaria Española, 1978.

${ }^{10}$ Quizá el más interesante sea el de fray Jerónimo de Feijoo, Cartas eruditas y curiosas, 1774, 187-203.

${ }^{11}$ Los ejemplos más interesantes al respecto se comentan adelante en el texto.
} 
Estas posturas encontradas propiciaron un extenso debate, que alcanzó a la mayor parte de los países europeos y que tuvo presencia no sólo en libros, pastorales y epístolas publicadas, sino también en periódicos. ${ }^{12}$ Tales discusiones dieron lugar al surgimiento de una doble lectura acerca de la masonería, con una vertiente positiva y una negativa -a las que en España se ha denominado filomasonería y antimasonería-, aunque ambas se alimentaban de los mismos elementos; es decir, de los argumentos desarrollados por las autoridades temporales y eclesiásticas.

$\mathrm{Al}$ parecer, antes de la consumación de la independencia las apologías de la masonería prácticamente no tuvieron presencia en Nueva Espańa, gracias al celo de la Inquisición y de las autoridades virreinales. Esto propició que en la Colonia las principales referencias que circularan acerca de esa sociedad fueran las de la antimasonería, representada por textos como el Centinela contra franc-masones (1752) de fray Joseph Torrubia y La falsa filosofia (1773-1776) de fray Fernando de Zeballos.

En su Centinela, Torrubia aparentaba develar algunos de los misterios masónicos -aunque con base en meras suposiciones- e informaba a sus lectores acerca de las señales de reconocimiento de los masones, sus rituales, juramentos y supuestas finalidades, a fin de que pudieran reconocerlos, delatarlos y evitaran involucrarse con ellos. También incluyó una traducción de la pastoral del obispo Justiniani, quien trataba de justificar las bulas papales con argumentos bíblicos, y señalaba que la masonería era "intrínsecamente mala", aun cuando en sus postulados no hubiera nada contrario a la religión ni a los soberanos. Según el prelado, la razón para que así fuera era el secreto y el riguroso juramento para no revelarlo, pues de acuerdo con una máxima de la religión cristiana sobre la luz y las tinieblas, los que obran mal no salen a la luz para que no se vea su mal obrar, pero los que obran bien no rehúsan salir al público. ${ }^{13}$ Es decir, el obispo de Vintimilla (Ventimiglia) consideraba el secreto de la

${ }^{12}$ Para un análisis muy completo de este debate véase Ferrer Benimeli, La masonería española en el siglo..., 1986 y Bibliografía..., 1978, passim.

${ }^{13}$ Ferrer Benimeli, La masonería española en el siglo..., 1986, 181. 
masonería como causa suficiente para sostener su maldad intrínseca, pues no era un secreto que estuviera justificado por la bondad de sus fines, como ocurría en el caso de la Inquisición.

Por su parte, la obra de Zeballos se insertó en una corriente que apareció en la metrópoli durante las últimas décadas del siglo XVIII -a la que algunos autores actuales han denominado reaccionaria, conservadora o contrarrevolucionaria-, que por un lado se oponía al absolutismo y a la pérdida de prerrogativas de la Iglesia, y por otro a los principios de la nueva filosofía, a la que llamaba falsa. ${ }^{14} \mathrm{En} L a$ falsa filosofía, Zeballos incluía a la masonería en el catálogo de sectas que estaban tratando de destruir la religión católica, por sostener ideas como el deísmo y la tolerancia religiosa, y que pretendían acabar con la fuerza de las monarquías sustentando principios contrarios a las regalías de los soberanos y de las potestades legítimas, todo lo cual, a su juicio, era resultado de la irreligión. Relacionaba a la masonería, al pensamiento ilustrado y a la filosofía moderna con el protestantismo, del cual, según el autor, emanaban todos los contratiempos políticos y morales de la época revolucionaria. ${ }^{15}$

Con este tipo de planteamientos, la imagen pública de la masonería quedó ineludiblemente vinculada con el pensamiento ilustrado y algunos principios liberales, pero con un sentido peyorativo, mediante un relato que, en primera instancia, no fue elaborado por los defensores de la asociación masónica, sino por sus detractores. ${ }^{16}$

Los postulados derivados de este tipo de textos, así como de los edictos monárquicos y las bulas papales, proporcionaron elementos a los inquisidores novohispanos para enfrentarse a los casos de francmasonería que comenzaron a presentárseles a partir de 1761. En los procesos que se siguieron contra masones entre ese ańo y 1790 pueden observarse posturas encontradas acerca de la masonería. Por un

${ }^{14}$ Véase Peer Schmidt, "Una vieja élite en un nuevo marco político: El Clero Mexicano y el inicio del conservadurismo en la época de las Revoluciones Atlánticas (17761821)", en Sandra Kuntz Ficker y Horst Pietschmann, México y la economía atlántica (siglos XVIII-XX), México, El Colegio de México, 2006, 67-105.

${ }^{15}$ Peer Schmidt, “Una vieja elite...”, 2006, 85.

${ }^{16}$ Jordi Canal, El Carlismo: dos siglos de contrarrevolución en España, Madrid, Alianza, 2000, 32-33. 
lado, los reos que aceptaban pertenecer a la orden o tener conocimiento de ella la catalogaban como "cosa buena", que no tenía nada contrario a la religión ni a la fe y que estaba formada por hombres de bien de todas las condiciones sociales, que se proporcionaban ayuda mutua. Por otro, los inquisidores relacionaban de manera necesaria la pertenencia a la francmasonería con el sostenimiento de principios contrarios a los de la Iglesia católica, que se traducían en la posesión de libros prohibidos y en el pronunciamiento de proposiciones heréticas, aunque estas últimas no tuvieran un vínculo directo con la masonería ni con sus postulados. También se mostraban preocupados porque los reos se negaban a revelar las señas de reconocimiento y los procedimientos de su admisión, porque tenían hecho juramento al respecto. ${ }^{17}$ Esta actitud expresa la necesidad que sentían las autoridades de no permitir que el juramento masónico se pusiera por encima del realizado ante las instituciones reconocidas, ya que ello implicaba una importante ruptura del orden establecido y era uno de los principales temores que la masonería despertaba: que ocasionara una pérdida de fuerza de las prácticas con las que hasta entonces se había regido la sociedad.

Aunque en Europa varios autores acusaban a la masonería de ser "enemiga del altar y el trono", en estas causas se percibe que en la Inquisición novohispana, hasta antes de 1790, la masonería era considerada principalmente como enemiga del altar; es decir, como una herejía, una secta que amenazaba la pureza de la religión y de sus dogmas de fe, al atreverse a cuestionar las verdades reveladas; y también como una institución que desvirtuaba las prácticas fundamentales del orden establecido. Pero aún no se le relacionaba directamente con los ataques a la monarquía.

Fue hasta que estalló la Revolución francesa en 1789 que la imagen de la masonería como enemiga del trono empezó a cobrar mayor fuerza. Las autoridades españolas de ambos lados del Atlántico mostraron gran temor de que los ideales revolucionarios se exten-

${ }^{17}$ Archivo General de la Nación (en adelante AGN), Inquisición, vol. 1008, exp. 2, fs 28-66; vol. 1079, exp. 9, fs. 204-245; vol. 1103, exp. 25, fs. 216-221; vol. 1114, s/e, foja 130; vol. 1223, exp. 5, fs. 20-53; vol. 1273, exp. 5, fs. 1-66; vol. 1248, s/e, fs. 119-121; vol. 1306, s/e, fs. 366-367; vol. 1340, s/e, fs. 28-32. 
dieran en su territorio. En diversos sermones y pareceres se procuraba reafirmar en los pueblos la obediencia y fidelidad al soberano, a fin de evitar que pudiera cundir la rebelión. Pocos ańos más tarde, en 1793, tras la decapitación de Luis XVI que ocasionó la participación de Espańa en la Guerra de la Convención, se acrecentó el clima de paranoia e inseguridad en dichas autoridades respecto a los franceses, sobre todo por el temor de que entre los súbditos hispanos se despertaran sentimientos francófilos u opuestos a la monarquía. ${ }^{18}$

Un sector de la Iglesia novohispana estaba convencido de que las acciones contra los monarcas franceses las habían ocasionado los filósofos, que pretendían destruir el orden establecido por Dios para el universo. ${ }^{19}$ Frente a ello, la teoría del complot masónico, que había comenzado a vislumbrarse desde los planteamientos del padre Rávago, fue adquiriendo su forma definitiva en diversas obras que se publicaron en Europa a partir 1790, cuyos autores hacían derivar a la Revolución francesa de una conjura masónica internacional destinada a derribar las monarquías y la Iglesia católica. ${ }^{20}$

Quien consolidó esta idea fue el abate Barruel, en sus Mémoires pour servir à l'histoire du Jacobinisme (1797). En su texto, la masonería aparecía al mismo tiempo como cerebro e instrumento de la Revolución francesa, a través de la organización jacobina. Barruel fusionó los ideales revolucionarios con los principios masónicos y con el extremismo jacobino, de un modo tal que logró hacer parecer que la Revolución francesa era el resultado de una conspiración internacional para acabar con el altar y el trono, que habría tenido su origen en el iluminismo bávaro y que había sido formulada por los filósofos y masones encabezados por Voltaire. ${ }^{21}$ Es interesante desta-

${ }^{18}$ Gabriel Torres Puga, "Centinela mexicano contra francmasones. Un enredo detectivesco del licenciado Borunda en las causas judiciales contra franceses de 1794", Estudios de Historia Novohispana, vol. 33, 2005, 62. José Antonio Ferrer Benimeli, "El discurso masónico y la Inquisición en el paso del siglo XVIII al xIx", Revista de la Inquisición, vol. 7, 1998, 270-271. Herrejón, “La revolución...”, 1992, 97-98. Marta Terán, "La Virgen de Guadalupe contra Napoleón Bonaparte. La defensa de la religión en el obispado de Michoacán entre 1793 y 1814", Estudios de Historia Novohispana, vol. 19, 1999, 91-129.

${ }^{19}$ Carlos Herrejón, "La revolución...”, 1992, 98.

${ }^{20}$ Ferrer Benimeli, La masonería española en el siglo..., 1986, 311-313.

${ }^{21}$ Agustín Barruel, Conspiración de los sofistas de la impiedad contra la religión y el es- 
car, como lo ha hecho Ferrer Benimeli, que hasta un declarado enemigo de esta asociación como Barruel hizo una distinción entre la verdadera y la falsa masonería; para él, la verdadera era la inglesa, que no tenía nada contrario al honor ni a la religión, mientras la falsa era la francesa, a la que catalogaba de herética y revolucionaria. ${ }^{22} \mathrm{~A}$ pesar del peligro que representaba el anglicanismo inglés, es claro que el enemigo a vencer estaba en Francia.

Tanto las autoridades temporales como el clero buscaron evitar que, a través de la masonería, se difundieran los ideales revolucionarios, a los que consideraban destructores, y el tribunal del Santo Oficio fue una de las principales armas que emplearon contra ello. Así, durante los últimos años del siglo XviıI aumentó en Nueva España el número de causas judiciales e inquisitoriales contra francmasones, en las que los aspectos políticos que había adquirido la imagen pública de la masonería comenzaron a tener mayor relevancia. Los síntomas del contagio revolucionario, expresados en pasquines favorables a los franceses, e incluso en algunos intentos de rebelión, así como la desconfianza e incertidumbre que despertaba la masonería como organización, dieron lugar a que las ideas europeas de una conspiración francomasónica cayeran en terreno fértil entre las autoridades novohispanas.

La llegada del marqués de Branciforte como nuevo virrey de la Nueva España contribuyó a esta persecución, pues muy pronto ordenó investigar el rumor de que había muchos franceses en la capital, que se reunían en tertulias y discutían asuntos políticos. ${ }^{23} \mathrm{En}$ los procesos seguidos a Juan Laussel, ${ }^{24}$ Juan Malvert, ${ }^{25}$ Vicente Lulié ${ }^{26}$ y

tado, o, Memorias para servir a la historia del jacobinismo, Madrid, Imprenta de Collado, $1814,4 \mathrm{Vol}$.

${ }^{22}$ Ferrer Benimeli, Bibliografia..., 1978, pp. 41-42. César Vidal, "Los Protocolos de los sabios de Sión”, Ideas. Libertad digital, 2002. Revista electrónica en: http://revista.libertaddigital.com/articulo.php/1275325957

${ }^{23}$ Gabriel Torres, "Centinela mexicano...", 2005, 62.

${ }^{24}$ AGN, Inquisición, vol. 1307, exp. 7, fs. 44-74; vol. 1369, exp. 9, fs. 96-116; vol. 1383, exp. 5, fs. 1-192.

${ }^{25}$ AGN, Inquisición, vol. 1239, exp. 7, fs. 442-524; vol. 1248, s/e, fs. 216-218.

${ }^{26}$ Archivo Histórico Nacional de Madrid, citado por Gabriel Torres, "Centinela mexicano...”, p. 67 y ss. AGN, Criminal, vol. 667, exp. 11, fs. 209-317. 
Juan Durrey, ${ }^{27}$ entre otros, persistió la preocupación de que la masonería afectara la religión, pero el recelo que generaba la crisis europea propició que los aspectos relacionados con el trono comenzaran a recibir mayor importancia que los del altar.

En estas causas, y varias más que se siguieron en 1794, los jueces, fiscales e inquisidores buscaron ubicar intentos de sedición de dichos franceses, quienes ya no sólo eran vistos como herejes enemigos de la Iglesia y la fe, sino sobre todo como emisarios que pretendían desestabilizar el orden monárquico para favorecer los principios de la Revolución francesa. Fue así como la teoría del complot masónico comenzó a tomar forma en Nueva España, pues para sus jueces, el hecho de que varios de los procesados pertenecieran a la masonería implicaba la posibilidad de que utilizaran el secreto de la orden, y los vínculos que mediante ella se podían establecer, para realizar sus "perversos" fines. Incluso, en el caso de Lulié, a quien no se había acusado de masonería, el traductor, Ignacio Borunda, acudió al Centinela de Torrubia para encontrar indicios de su pertenencia a la orden. ${ }^{28}$

Algunos historiadores, masónicos y académicos, han sostenido que dichos franceses fueron precursores ideológicos de la independencia, por cuestionar el orden monárquico y difundir la filosofía de la Ilustración. ${ }^{29}$ Incluso hay quienes consideran que, efectivamente, formaron parte de una conspiración. ${ }^{30}$ Por el contrario, Gabriel Torres ha señalado que fue el clima de inseguridad y paranoia lo que propició que se magnificaran las culpas de este grupo de franceses, que al parecer más que propagadores de ideas subversivas o conspiradores, eran simplemente personas preocupadas por lo que ocurría en su país en la guerra contra España. ${ }^{31}$ Independientemente de si fueron conspiradores o no, para esta investigación lo

${ }^{27}$ AGN, Inquisición, vol. 1357, exp. 4, fs. 1-68; vol. 1248, s/e, fs. 216-218.

${ }^{28}$ Gabriel Torres, "Centinela mexicano...”, passim.

${ }^{29}$ Rangel, La vida colonial..., 1932. Zalce, Apuntes..., 1950, 9.

${ }^{30}$ Víctor M. Uribe-Uran, "The Birth of a Public Sphere in Latin America during the Age of Revolution", Comparative Studies in Society and History, vol. 42, núm. 2, abril 2000, 431.

${ }^{31}$ Gabriel Torres, “Centinela mexicano...”, 2005, 65. 
que resulta fundamental es el hecho de que las autoridades novohispanas y los propios delatores los hayan catalogado como tales, pues ello evidencia el eco que comenzaba a tener la teoría del complot masónico. Predominaba la opinión negativa sobre la masonería, no sólo en la Inquisición y la Corte, sino también entre la gente común, pues hubo varias delaciones espontáneas contra francmasones.

Con ello puede constatarse que en Nueva España, apenas diez ańos antes del inicio de la lucha por la independencia, la masonería generaba todavía un profundo rechazo, que estaba bastante generalizado entre los distintos sectores sociales que tenían nociones de su existencia, excepto en muy reducidos espacios donde existía una incipiente visión positiva acerca de ella, difundida en muy pequeña escala por los pocos masones que habitaban la Colonia.

Privaba la cultura política de una monarquía católica, que fundaba la autoridad del soberano en la voluntad divina, daba por hecho el armonioso funcionamiento de la sociedad corporativa basada en privilegios otorgados por el rey, y temía a las transformaciones que podían derivarse de un contexto convulsionado por el pensamiento dieciochesco, la Revolución francesa y el inicio del imperio napoleónico. En esas condiciones, sólo podía despertar sospechas y recelos una asociación como la masonería, que tenía prácticas que se entendían como contrarias a las máximas de la fe, como el secreto y la aceptación de otras creencias; a la que se identificaba con principios que muchos consideraban heréticos como la soberanía del pueblo; o que actuaba al margen del orden establecido por detentar prerrogativas que no le habían sido conferidas por las autoridades legítimas.

\section{LAS IDEAS SOBRE LA MASONERÍA FRENTE A LA CRISIS DE LEGITIMIDAD}

Varios autores sostienen que las transformaciones políticas que se suscitaron a partir de 1808 en los territorios hispánicos de ambos hemisferios tuvieron raíces tradicionales, pues se fundamentaron más en la teología, en el constitucionalismo histórico, en las tesis del jusnaturalismo racionalista y en la lectura de Francisco de Vitoria y 
de Francisco Suárez, que en la filosofía ilustrada francesa. ${ }^{32}$ Esta última generaba temor y desconfianza, sobre todo a causa de los excesos cometidos durante la Revolución francesa y de la forma en que Napoleón se estaba apropiando de algunos de los principios que la habían animado para extender su imperio.

La invasión napoleónica a España y la abdicación del rey ocasionaron una crisis de legitimidad que propició un profundo cuestionamiento de los principios que fundamentaban la autoridad pública. La pérdida del referente trascendental que legitimaba la monarquía hizo necesario recurrir a algunos conceptos modernos, que se enfrentaron o superpusieron con las ideas y la constitución social existentes. Esto abrió la posibilidad de que los conceptos y las prácticas en que se sustentaba el orden político fueran reinventados o planteados de distintas formas. ${ }^{33}$ Naturalmente, muchos autores rechazaban la adopción de los principios emanados de las nuevas doctrinas, e incluso de las antiguas, y pretendían contrarrestarlos a través de diversos escritos, en los que el tema masónico cobró mayor importancia, pues aparecía ligado con la discusión de dichos principios.

Según José A. Ferrer Benimeli, en Europa la masonería había decaído tras la Revolución francesa, y muchas logias habían desaparecido, aunque no por ello las ideas de que esta asociación había planeado y organizado la revolución dejaron de condensarse en la teoría del complot. Cuando Napoleón arribó al poder en Francia, empleó a la masonería como herramienta de propaganda de su persona y de su imperio y la transformó en un instrumento de difusión de los principios revolucionarios -que se incluyeron en reglamentos, canciones y discursos-, favoreciendo la instalación de numerosas logias dentro y fuera de Francia, tratando de unificar a la masonería francesa, e incorporando a diversos masones como funcionarios de su régimen. ${ }^{34}$

${ }^{32}$ Luis Villoro, “La revolución...”, 2000, 499. Ávila, “Interpretaciones recientes...”, 2007, 23.

${ }^{33}$ Elías Palti, El tiempo de la política. El siglo XIX reconsiderado, Buenos Aires, Siglo XXI Editores Argentina, 2007.

${ }^{34}$ Grand Orient de France, "La evolución [de la francmasonería] del siglo xIx y de la primera mitad del siglo xx", en www.godf.org/foreign/es/histoire_es_02c.html. José A. Ferrer Benimeli, La masonería española, Madrid, Istmo, 1996, 39. 
En la invasión a España llevó consigo esta tendencia y estableció la masonería bonapartista. En sus diversos papeles, esta masonería se presentó a sí misma como "la antítesis de la Inquisición y del despotismo religioso", mientras los masones se autodenominaron los enemigos de la intolerancia, la superstición, la ignorancia y el fanatismo. ${ }^{35}$ Así, la masonería volvió a quedar identificada con los principios e ideales revolucionarios, pero ya no sólo en un discurso construido por sus detractores, sino ahora también por algunos de sus apologistas y por aquellos que buscaban convertirla en un instrumento para legitimar y afianzar su poder.

Tras el triunfo de la Revolución francesa y el establecimiento de los nuevos sistemas políticos, esa línea argumentativa que anteriormente llevaba una carga peyorativa, contraria al pensamiento ilustrado o revolucionario, se transformó en una lectura positiva que convertía a la masonería en la impulsora de las grandes transformaciones políticas y sociales, que efectivamente acabarían con los abusos del altar y el trono, como tanto habían temido sus primeros combatientes. La lectura positiva se volvió así una interpretación que vinculaba de manera directa a la masonería con ideas como el uso de la razón, la igualdad y la soberanía del pueblo. En función de esta perspectiva, sus apologistas la presentaron como simiente y difusora de principios y prácticas benéficas para la sociedad.

Sin embargo, en los territorios hispánicos las bases del nuevo sistema adoptado -las juntas, el establecimiento de las Cortes de Cádiz y la promulgación de la Constitución de 1812- no tenían su principal raíz en el pensamiento francés que animaba la masonería bonapartista. En consecuencia, la invasión de Napoleón a España, lejos de lograr una aceptación de la masonería, incrementó la fobia contra ella. Como resultado, en la metrópoli adquirió mayor fuerza la literatura antimasónica, dentro del discurso revolucionario, mediante el cual se manifestó el rechazo a todas las modificaciones que estaba sufriendo el orden político y social. Los temores iniciales de Rávago de que un monarca ambicioso utilizara a la masonería para dominar el mundo parecieron cumplirse en la persona de Napo-

${ }^{35}$ Ferrer Benimeli, La masonería española, 1996, 39. 
león, por lo que las obras que lo vinculaban con la asociación masónica proliferaron ampliamente, sobre todo con la intención de contrarrestar el influjo de las ideas que difundía la masonería bonapartista. Un ejemplo de esta campaña fue una serie de artículos publicados en El Sol de Cádiz, en la que los masones aparecían como los enemigos del rey y de la "Religión Santa". ${ }^{36}$

Algunas de esos textos antimasónicos cruzaron el Atlántico y llegaron a las posesiones americanas. El más conocido de ellos que se publicó en Nueva España, en 1809, fue el Despertador Christianopolítico. Su autor, el presbítero Simón López, consideraba que los ayudantes de Napoleón eran los filósofos, deístas, ateístas, herejes, apoyados en la "cábala infernal" que era la francmasonería. Articulaba los argumentos de las primeras prohibiciones monárquicas y eclesiásticas con los de la teoría del complot y algunos que parecían de su particular inspiración. Describía a la masonería como una institución basada en una serie de ridiculeces, supersticiones y profanaciones. Según su planteamiento, los individuos que a ella pertenecían elaboraban terribles juramentos para guardar el secreto y prometían obediencia ciega a sus jefes, quienes procuraban ocultar sus fines, pues las clases inferiores no sabían los misterios de las medianas, ni éstas de las superiores hasta que llegaban a ellas. ${ }^{37}$

Le atribuía el origen de la orden a Cromwell, siguiendo la línea del discurso contrarrevolucionario que relacionaba a la masonería con el protestantismo y con las ideas antimonárquicas, según la cual la masonería tenía una tendencia hacia la libertad natural, al odio a toda autoridad soberana y creía que la obra más grata a Dios sería destruir la tiranía y las tinieblas de la ignorancia. ${ }^{38}$ Desde esa perspectiva, la masonería y el protestantismo se habrían unido para trastocar todo el orden existente.

López sostenía que los masones pretendían destronar a los reyes católicos para que no pudieran defender la religión, y así se lograra instaurar primero el deísmo y luego el ateísmo. Para este autor, el fin

${ }^{36}$ Ferrer Benimeli, La masonería española, 1996, 56-57.

${ }^{37}$ Simón López, Despertador Christiano-Político, Murcia, reimpreso en México por Juan López de Cancelada, 1809, passim.

${ }^{38}$ Ferrer Benimeli, La masonería española en el siglo..., 1986, 246-247. 
de la masonería no era político sino espiritual, pues la intención de destruir los tronos era únicamente privar de su apoyo a la Iglesia y así imponer el deísmo o el materialismo. Según él, la propuesta republicana y la decantada igualdad de los masones habían sido sólo la pantalla para engañar a los incautos y al pueblo, pero sus verdaderos fines eran otros. ${ }^{39}$ Evidentemente, los postulados deístas de autores como Voltaire y Rousseau, la promulgación en Francia de la Constitución Civil del Clero y el establecimiento del culto al Ser Supremo, junto con los principios que sostenía la masonería napoleónica, proporcionaban los elementos para estas afirmaciones.

López utilizó los propios principios republicanos y liberales que la masonería había sostenido para deslegitimarla, lo cual resultaba particularmente útil en ese momento, para contrarrestar la aparente buena voluntad del gobierno napoleónico y evitar que los espańoles se unieran a él, pues si políticamente la monarquía de José Bonaparte parecía una opción viable para algunos, el supuesto peligro que corría la religión no permitiría que la población lo aceptara. Además, el presbítero creía que con sus afirmaciones los partidarios del gobierno republicano podrían darse cuenta de que la masonería no era el camino para llegar a él. De este modo, los argumentos que anteriormente se desarrollaban en contra de la masonería en abstracto, o de la Revolución francesa allende las fronteras hispanas, ahora se convertían en elementos para atacar a un enemigo político concreto.

\section{LAS IDEAS SOBRE LA MASONERÍA DURANTE EL PROCESO DE INDEPENDENCIA}

A pesar de que, en los últimos 50 años, algunos autores han insistido en que las primeras fases de la insurgencia tuvieron raíces más tradicionales -como las tesis de los teólogos populistas ${ }^{40}$-, la percepción de que la rebelión era un movimiento impulsado por Napoleón y por las ideas revolucionarias de los franceses tuvo eco entre varios escritores novohispanos, quienes la concebían como parte del

\footnotetext{
39 Simón López, Despertador..., 1809, passim.

${ }^{40}$ Carlos Herrejón, Hidalgo..., 1987, 15-42.
} 
plan napoleónico para acabar con la monarquía católica y extender su imperio por todo el orbe. Como ha señalado Alfredo Ávila, estas afirmaciones fueron elaboradas por los publicistas realistas para desprestigiar a los insurgentes, ${ }^{41}$ pero es preciso tener claro que, en su momento, tales asertos no parecían carecer de sustento: la literatura antimasónica, antinapoleónica y contrarrevolucionaria les proporcionaba los elementos para asegurar la existencia de tal conjura.

En un primer momento, la relación entre la insurgencia y los franceses apareció en los papeles públicos novohispanos más como resultado del complot napoleónico que del masónico. Entre 1810 y 1812, autores como José Mariano Beristáin y Juan Bautista Díaz Calvillo aseguraban que Miguel Hidalgo había tenido una entrevista con el general francés Octaviano D'Alvimar, quien al parecer era un enviado de Napoleón que debía ponerse al mando del que creía virrey en México en ese momento, el marqués de S. Simón. ${ }^{42}$ Según Beristáin, D’Alvimar formuló con Hidalgo los planes para la sublevación, gracias a la cual el "infame corso [había conseguido] introducir ya en nuestro inmaculado suelo el aguilucho o gavilán estuprador que intenta violar nuestra águila mexicana”. ${ }^{43}$ Carlos María de Bustamante consideraba que las aseveraciones de Beristáin eran "una patrańa”, pues D'Alvimar, a quien conoció cuando regresó a México durante el imperio de Iturbide, le parecía un hombre "muy servil en sus opiniones políticas", "más propio para llevar a efecto un gobierno militar y bárbaro"; ${ }^{44}$ sin embargo, algún impacto tuvieron, pues pronto comenzó a afirmarse como un hecho la relación entre la insurrección de Hidalgo y la conjura napoleónica.

Con ello el terreno estaba sembrado para que el tema masónico alcanzara una importante dimensión durante la contienda indepen-

${ }^{41}$ Alfredo Ávila, “Interpretaciones recientes...”, 2007, 18.

${ }^{42}$ Carlos María de Bustamante, Suplemento de la historia de los tres siglos de México, Carta Séptima, en Boletín del Archivo General de la Nación, tomo viI, núm. 2, abril-junio 1936, 163. Ávila, “Cuando se canonizó...”, en prensa.

${ }^{43}$ José Mariano Beristáin, "Diálogos entre Filopatro y Aceraio", en Juan E. Hernández y Dávalos, Colección de documentos para la historia de la guerra de independencia de México, documento núm. 257, edición bajo la dirección de Alfredo Ávila y Virginia Guedea, en www.pim.unam.mx, México, unAm, 2009.

${ }^{44}$ Bustamante, Suplemento... 1936, 163. 
dentista. La literatura antimasónica y antinapoleónica aseguraba la existencia de un complot entre Napoleón, el pensamiento revolucionario y la masonería para acabar con el altar y el trono; los postulados de la masonería bonapartista se apropiaban del lenguaje liberal y de los principios de la filosofía dieciochesca; y existía la convicción, entre numerosos realistas, de que un movimiento como el insurgente -al que consideraban herético- sólo podía derivarse de la perniciosa influencia francesa. En este contexto adquirieron sentido los planteamientos que permitieron afirmar que la insurgencia era instigada por la francmasonería.

Por tal razón, como se verá a continuación, fueron principalmente los defensores del orden colonial quienes discutieron sobre la masonería y la insurrección. Sin embargo, los insurgentes también escribieron al respecto, pues consideraban que la masonería era uno de los principales enemigos que combatir en la Península, ya que era la causa y el medio de la invasión napoleónica. Esta coincidencia es una muestra de la semejanza discursiva entre la insurgencia y la contrainsurgencia -que ya ha sido mostrada por Rafael Rojas ${ }^{45}$ - y de la existencia de un lenguaje político compartido dentro del cual se movían ambos bandos, aun cuando poco a poco las posturas se fueron radicalizando. El hecho de que tanto realistas como independentistas hayan dado a su lucha un contenido religioso propició que aumentara la percepción de la masonería como un peligro, pues para ambos ésta era el instrumento del herético enemigo que compartían: Napoleón.

Algunos de los autores que buscaban mantener la unión con la monarquía espańola, y evitar los brotes autonomistas e independentistas, consideraban que el complot masónico había por fin llegado a América, para generar la división y la discordia entre los novohispanos y destruir el imperio de Fernando VII. Dos de los más destacados exponentes de estas ideas fueron José Ximeno y Agustín Pomposo Fernández de San Salvador.

Ximeno publicó, en 1811, su contestación al manifiesto de Hidalgo, en la que desarrolló con amplitud las que consideraba here-

${ }^{45}$ Rafael Rojas, La escritura..., 2003, 53. 
jías y errores del insurgente y las razones por las que la rebelión le parecía injusta e impía. Todo ello con la finalidad de que "los seducidos depongan su engańo, abracen la justicia, sigan la verdad, y este felicísimo reino vea restituida la paz, el buen orden la tranquilidad y gloria que llora más de seis meses perdidas" ${ }^{46}$

En su texto, fray José siguió la línea de autores y predicadores como Manuel Abad y Queipo o Miguel Diego Bringas y Encinas, consolidada en textos como el Anti Hidalgo, en los que se catalogaba al cura de Dolores, entre otras cosas, de hereje luterano. ${ }^{47}$ Y empleó esos argumentos para combatir los principios del derecho natural y la idea de la soberanía popular. Para este fraile, el hecho de que Hidalgo pretendiera legitimar sus actos por el poder que le había conferido la plebe era herético, porque la plebe era la parte menor y más perdida de la sociedad, que de acuerdo con las normas de la fe debía estar sometida a su legítima potestad y no tenía ningún derecho para sustraerse a su obediencia. Otra herejía que Ximeno encontraba en Hidalgo era que este último había sostenido que podía absolver a los súbditos del juramento de fidelidad para recobrar sus derechos originales, con lo cual impugnaba un derecho divino. $\mathrm{Y}$ aseguraba que Hidalgo había aprendido esa idea en la escuela de "sus hermanos los francmasones", que enseñaban una igualdad en la que sin diferencia alguna todos eran iguales para todo, con la sola elección de sus hermanos. Para Ximeno esa era la que llamaba "perniciosa igualdad" de los liberales y francmasones, la que disolvía las diferencias que daban orden a la sociedad y generaban la anarquía.

Fray José aseguraba que los francmasones promovían la rebelión porque la consideraban indispensable para lograr la regeneración del mundo que pretendían; con este fin celebraban juntas nocturnas en las que discutían los medios y planes para dar sus golpes, y engañaban a los incautos proclamando la felicidad, gloria y libertad, y la lucha por sacudir el yugo de la tiranía. Y afirmaba que eso mismo

${ }^{46}$ José Ximeno, Contestación de fray JosefJimeno, del colegio de cruciferos de Querétaro, al manifiesto del señor Hidalgo, 1811; en Hernández y Dávalos, Colección..., documento núm. 219, 2009.

${ }^{47}$ Alicia Mayer, Lutero en el Paraíso. La Nueva España en el espejo del reformador alemán, México, FCE/IIH, UNAM, 2008, 352-371. 
había hecho Hidalgo, formar juntas nocturnas para sus planes de rebelión, con el pretexto de alcanzar la gloria y libertad de América; en consecuencia para Ximeno no cabía duda de que Hidalgo era masón y que el yugo que pretendía sacudir era el de la ley y religión de Jesucristo.

Como muchos otros opositores de la insurgencia, el autor de la Contestación estaba convencido de que el protestantismo había sido el antecedente de las obras de filósofos como Hobbes, Espinosa y Voltaire, todo lo cual había atacado las máximas de la fe y las costumbres cristianas, introducido la rebelión, mermado la autoridad eclesiástica y secular, ${ }^{48}$ y ocasionado las herejías del cura de Dolores, que lo llevaban a negar la verdad revelada y a sostener que la religión era sólo política e invención de los hombres.

Poco después, en 1813, Ximeno publicó otra obra, La verdadera felicidad, libertad e independencia de las naciones, en la que repetía algunos argumentos que ya había empleado en 1811 acerca de que la insurgencia era contraria a la ley divina, y señalaba que había sido impulsada por los argumentos de los falsos filósofos, a quienes identificaba con los francmasones. Éstos, con el pretexto de buscar la felicidad y la libertad de la nación, y sacudir el yugo de la tiranía, la llevaban a su perdición, separándola de la religión y obligándola a repudiar a su legítimo soberano. ${ }^{49}$

Estas afirmaciones permiten constatar que fueron los detractores del movimiento insurgente quienes, desde sus inicios, lo presentaron como resultado de la influencia de la filosofía francesa y por consiguiente de la masonería, lo cual no era gratuito dada la imagen pública de la masonería que provenía de Europa. El propio Ximeno dejó indicado cuáles eran las obras en que se había inspirado para elaborar la idea que ofrecía acerca de la francmasonería: el Centinela de Torrubia, la Vida de Cagliostro y el Despertador de Simón López. Era la literatura antimasónica, que comenzaba a ser reinterpretada en Nueva Espańa, a la luz de la cultura política de una monarquía

\footnotetext{
${ }^{48}$ Alicia Mayer, Lutero..., 2008, 377-380.

${ }^{49}$ José Ximeno, La verdadera felicidad, libertad e independencia de las naciones, México, Impreso en la casa de Arizpe, 1813, passim.
} 
católica para la cual los acontecimientos que estaban teniendo lugar en la metrópoli y en América estaban atentando contra el orden establecido, usurpando la potestad divina, desdeńando la verdad revelada y rompiendo los lazos que daban cohesión y armonía a la sociedad, al cuestionar los fundamentos trascendentales de la autoridad. Para esa cultura política, los insurgentes eran herejes, enemigos del altar y el trono, y por lo tanto masones. Por ello, aunque Hidalgo y otros líderes insurgentes hicieran profesión pública de su fe católica y de su respeto al monarca, eran vistos de inmediato como agentes de la conspiración que tenía como finalidad disolución del cuerpo político.

A pesar del importante trabajo de Ximeno, fue Agustín Pomposo Fernández de San Salvador quien mejor sistematizó las ideas de la literatura antimasónica, vinculándolas con la insurrección de Hidalgo. En sus obras la insurgencia aparecía como una vertiente de la conspiración masónica para acabar con el altar y el trono, que ahora tenía como finalidad ulterior consagrar en todo el orbe el imperio napoleónico "de religión e impiedad". En sus Desengaños que a los insurgentes de N. España, seducidos por los fracmazones agentes de $\mathrm{Na}$ poleón, dirige la verdad de la religión católica y la experiencia (1812), Fernández de San Salvador intentaba demostrar que a los insurgentes se les había engañado haciéndoles creer que estaban luchando por el rey y por la religión, pero que en realidad estaban sirviendo como instrumento para las maquinaciones de Napoleón, con cuyos malignos enviados, los francmasones, estaban coaligados los cabecillas del movimiento.

Para él, la francmasonería era el medio ideal para engañar a los rebeldes, porque en su tenebroso sistema todo se hacía en tinieblas y reservas, tanto que su principal jefe se llamaba "maestro invisible", porque entre los mismos que le obedecían eran muy pocos quienes le conocían. ${ }^{50}$ Fernández de San Salvador seguía la línea argumentativa de López, en la que el secreto masónico ya no sólo permitía que

${ }^{50}$ Agustín Pomposo Fernández de San Salvador, Desengaños que a los insurgentes de $N$. España, seducidos por los fracmazones agentes de Napoleón, dirige la verdad de la religión católica y la experiencia, México, Oficina de D. Mariano de Zúniga y Ontiveros, 1812, 48. 
al interior de la orden se fraguaran maldades, sino propiciaba que sólo sus miembros más elevados conocieran sus verdaderos fines, lo cual hacía que quienes se iniciaban en ella no supieran que estaban siendo utilizados para el mal.

Señalaba además que los masones conocían la fuerza de la palabra y se apoyaban en los más célebres, pero herejes e impíos, escritores para instigar a los insurgentes a sublevarse contra las autoridades establecidas, a pesar de que ello estaba absolutamente prohibido por el Evangelio, pues la obligación de los verdaderos cristianos era vivir subordinados a los reyes que Dios había puesto en los tronos, y no a los que cada uno se quisiera dar. Es decir, negaba los principios del derecho natural y en particular el derecho de los pueblos a elegir a sus soberanos, pues en su forma de concebir el mundo, ésta era una potestad divina, no humana. Y aseguraba que, en el último de los casos, si el gobierno era injusto, la legislación española ofrecía caminos para reclamar y reparar los daños, así como para castigar a sus autores, por lo que no era necesario recurrir a la sublevación.

De esta obra se imprimieron al menos 500 ejemplares, 30 de los cuales se obsequiaron al virrey, a varios obispos y al comandante general de las Provincias Internas. Entre los suscriptores que aportaron el apoyo económico para poderla imprimir se encontraban religiosos regulares y seculares, miembros de la nobleza, inquisidores, fiscales, impresores como Mariano Ontiveros y José María Benavente, y algunos otros miembros de la sociedad, incluidas varias mujeres. Todas estas personas recibieron un ejemplar y los restantes se vendieron a $31 / 2$ reales. Estos datos permiten observar que obras como ésta iban dirigidas a un público letrado y en principio tradicionalista, que pretendía conservar el orden establecido, preservarlo de los embates de las nuevas ideas y de los que llamaban "desvaríos" de los insurgentes. Sin embargo, con ella también se procuraba alertar a quienes podían ver con alguna simpatía la insurrección, deslegitimándola al convertirla en una intriga napoleónica organizada a través de la francmasonería.

La situación para la insurgencia se complicó cuando se descubrió en Xalapa una ramificación de la Sociedad de Caballeros Raciona- 
les, que tenía algunos elementos masónicos ${ }^{51} \mathrm{y}$ había sido fundada en Cádiz por un grupo de americanos, encabezados por Carlos Alvear, para buscar la independencia de los dominios hispanos en América. Esta agrupación estuvo directamente vinculada con las actividades de los insurrectos de la zona, y con la formación de la Junta Gubernativa Provisional de Naolingo, pero pronto fue descubierta y a los implicados se les condenó a muerte..$^{52}$

Se ha discutido mucho si la Sociedad de Caballeros Racionales fue o no una organización realmente masónica, ${ }^{53}$ pero lo importante para esta investigación es que varios personajes novohispanos tuvieron la clara percepción de que sí lo fue y así lo expresaron en diversos papeles públicos y privados, como los del obispo de Michoacán, Manuel Abad y Queipo:

Yo probé en otros escritos que existe una poderosa coalición de enemigos del Estado, que promueve la independencia de las Américas con mano oculta, con la astucia más profunda y con el maquiavelismo más refinado [...] Felizmente se interceptaron algunos papeles que no dejan lugar a duda de la materia. Por ellos se manifiesta que esta coalición se agregó a la secta de los francmasones, o que adoptó sus fórmulas y misterios. Se ve también que data de por lo menos de ocho a diez años, pues en 1810 había ya establecidas las logias tituladas de Racionales Caballeros en Cádiz, Londres, Filadelfia y Caracas. Son prodigiosos y en sumo grado temibles los efectos

${ }^{51}$ Sus miembros se daban el tratamiento de "hermanos" y denominaban logias a sus agrupaciones. Véase [Carta de Carlos Alvear a don Rafael de Mérida], 28 de octubre de 1811, AGN, Indiferente de Guerra, vol. 22, s/e, 27-28.

${ }^{52}$ Virginia Guedea, "Una nueva forma de organización política: la sociedad secreta de Jalapa 1812", en Amaya Garrita, ed., Un hombre entre Europa y América. Homenaje a Juan Antonio Ortega y Medina, México, UNAM/IIH, 1993, 189-190.

${ }^{53}$ Entre las obras en las que se considera a la Sociedad de Caballeros Racionales como una logia masónica destacan las de Zalce, Apuntes..., 1950, 28-40; Enrique de Gandía, "La vida secreta de San Martín", Todo es Historia, núm. 16, agosto de 1968, 8-19; Jiménez Codinach, La Gran Bretaña..., 1991, 265-289. Entre las que sostienen lo contrario se encuentran: José Antonio Ferrer Benimeli, "Las Cortes de Cádiz, América y la masonería", Cuadernos Hispanoamericanos, núm. 460, octubre 1988, 7-34; Pedro Pascual, "Ausencia de periódicos y libros masónicos en la Independencia de América", AIH, Actas XII, 1995, 194-202; Emilio Ocampo, "Inglaterra, la masonería y la independencia de América”, Todo es Historia, núm. 463, febrero de 2006, 6-21. 
de sus maquinaciones y cábalas dentro y fuera de la monarquía; en Nueva España, manejó desde el principio la gran masa de los pueblos, indios, negros y mulatos, con suma destreza, pues en menos de quince días puso en rebelión más de un millón de habitantes y los convirtió momentáneamente de hombres sumisos y pacíficos en monstruos feroces, que todo lo metieron a sangre y fuego. ${ }^{54}$

Esta clase de afirmaciones dieron sustento a las ideas de quienes incorporaban el movimiento insurgente al complot masónico, idea que años más tarde sería adoptada tanto por los defensores como por los detractores de la masonería y de los ideales y principios que se le adjudicaron a la insurgencia.

\section{MASONERÍA Y LIBERALISMO GADITANO}

En 1810, tras una serie de conciliaciones entre las distintas juntas de defensa contra Napoleón que se habían organizado en Espańa, se estableció la Junta Suprema Central Gubernativa, se nombró una Regencia y se convocó a Cortes, las cuales se reunieron en Cádiz con la finalidad de redactar una constitución. Con diputados de ambos hemisferios, esas Cortes dictaron medidas que ocasionaron profundas reformas en el orden político: establecieron principios como la soberanía de la nación, un gobierno representativo, la división de poderes, la disposición de bienes del clero, la supresión de algunas órdenes monacales y de la inquisición.

Este tipo de medidas fueron fácilmente identificadas con los tópicos de las doctrinas políticas que diversos autores habían denominado la "falsa filosofía". En 1813, Fernández de San Salvador promovió la edición en Nueva España del Preservativo contra la irreligión, de fray Rafael Vélez, quien se lamentaba de que en los papeles públicos de los liberales peninsulares se estaba abandonando el fundamento religioso de la autoridad pública y la figura de Fernando VII;

${ }^{54}$ Informe del obispo Manuel Abad y Queipo a Fernando VII, citado por Octavio Casa Madrid Mata, Los orígenes de la Francmasonería en México, México, Academia de Historia de la Masonería, 2003, 28. 
de que se proclamara la lucha contra el fanatismo y la superstición; de que las Cortes dispusieran de los bienes del clero y de que hubiera quien osara sugerir la tolerancia religiosa. Veladamente, Vélez mostraba temor de que entre los legisladores gaditanos hubiera algunos partidarios de la filosofía francesa, que creía llevaría a la destrucción de la monarquía y la religión. Siguiendo la línea del discurso antimasónico, identificaba a los liberales con los falsos filósofos y, por ende, con los masones. ${ }^{55}$

José de San Bartolomé seguía esa misma línea, pues en su Duelo de la inquisición aseguraba que la supresión del Santo Oficio redundaría en que se multiplicaran las logias masónicas, y que los francmasones lograran su finalidad de destruir el altar y el trono, para establecer el reino de la filosofía, mediante la difusión del lenguaje liberal, de voces como "la igualdad y libertad, la regeneración y felicidad de la patria", que ya habían expandido a través de la Revolución francesa. Según San Bartolomé, los medios de que los masones se habían valido para remover la religión revelada y la monarquía católica eran, entre otros, "la disputa de jurisdicción eclesiástica y civil, del Papa y de los obispos; el descrédito del clero secular y regular, la ocupación de los bienes eclesiásticos y empobrecimiento del clero; la supresión de los establecimientos piadosos; la tolerancia filosófica [y] la libertad ilimitada de la prensa". ${ }^{56}$

Así, el relato que identificaba a los liberales, los falsos filósofos y los masones no sólo alcanzaba a los insurgentes, sino también a los diputados gaditanos, a quienes estos autores no se atrevían a atacar directamente, pues eran la autoridad que reconocían como legítima y cuya legislación, la Constitución de Cádiz, estaba vigente; pero sí prevenían a los lectores del peligro que ellos creían que podía derivarse de que algunos de esos diputados estuvieran imbuidos de la falsa

${ }^{55}$ Rafael Vélez, Preservativo contra la irreligión, o los planes de la falsa filosofia contra la religión y el estado, Reimpreso en México en la oficina de doña María Fernández de Jáuregui, 1813.

${ }^{56}$ José de San Bartolomé, El duelo de la inquisición o pésame que un filósofo rancio de la América Septentrional da a sus amados compatriotas los verdaderos españoles por la extinción de tan santo y utilísimo tribunal, Madrid, Impreso por Don Francisco Martínez Dávila, 1814. Según se señala en la advertencia del editor, el texto fue escrito por San Bartolomé el año anterior, en la Nueva España. 
filosofía, y por tanto involucrados con la francmasonería, pues ello implicaba que disputaran la potestad divina, confundieran lo falso con lo verdadero, y supusieran que los hombres, por ser libres, dejaban de ser religiosos. La pérdida del fundamento trascendental de la autoridad implicaba, para estos publicistas, abrir la puerta a la anarquía, a la rebelión, a la ruptura del orden, pues en la cultura política de la monarquía católica, el elemento religioso era un factor fundamental de cohesión del cuerpo político, que se articulaba en torno a la cabeza, que era el rey, designado como tal por voluntad divina.

Por su parte, en los impresos independentistas también se observa la presencia de algunas ideas antimasónicas, particularmente las que asociaban a la masonería con Napoleón y con los liberales peninsulares. Los insurgentes no desarrollaron con la misma profundidad que los tradicionalistas la vinculación entre la masonería y los principios revolucionarios; seguramente porque ellos utilizaban - por lo regular con fundamentos más tradicionales de lo que parecía- parte de ese lenguaje que se consideraba subversivo y que se asociaba con la masonería, como los principios que sostenían que la soberanía residía esencialmente en los pueblos y que éstos eran libres para reformar sus instituciones políticas. Sin embargo, sí empleaban algunos de los planteamientos de la antimasonería como herramienta para justificar la sublevación y deslegitimar a los realistas.

Desde el "patriotismo contrailustrado", como lo define Rojas, el discurso de los sublevados, en los primeros años, consideraba ilegítimo al gobierno virreinal por oponerse a la verdadera lucha en favor de Fernando VII y la religión, que era la que los insurgentes estaban realizando. Por ello, en el periódico Ilustrador Nacional, el virrey Francisco Xavier Venegas era seńalado como ateo, materialista y masón. Quienes escribían en dicha publicación aseguraban que los franceses habían llevado la herejía a España y que los afrancesados peninsulares estaban dispuestos a entregarse a Napoleón y sus secuaces, mientras los "verdaderos americanos" luchaban por desatarse del yugo y conservar intacta la fe, que tan atacada se encontraba en Europa por la "multitud de logias de francmasones" que la tenían corrompida. ${ }^{57}$ 
Pero los insurgentes no sólo consideraban ilegítimo al gobierno virreinal, sino también al gaditano, pues según el Semanario $p a-$ triótico americano, éste estaba formado únicamente por los intereses de los comerciantes que, lejos de buscar la conciliación con los americanos insurreccionados, trataban de obtener apoyo económico de los "clubes de francmasones" para enviar tropas contra los mexicanos. ${ }^{58}$

Un poco más tarde, en 1813, cuando la insurgencia comenzaba a abandonar el patriotismo contrailustrado, persistía la idea de que una de las razones por las que era preciso separarse de la metrópoli era porque en ella dominaba la francmasonería. ${ }^{59}$ Carlos María de Bustamante se refería a Morelos como el caudillo que lograría librar al pueblo de la servidumbre en que le habían hecho caer los gachupines y quien evitaría que fuera entregado al deísmo y al politeísmo del "francmasonismo napoleónico". ${ }^{60}$ Meses después plasmaría la misma idea en el discurso que elaboró para que fuera pronunciado por Morelos ante el Congreso de Chilpancingo, el 14 de septiembre de 1813, en el que se señalaba que la soberanía residía esencialmente en los pueblos, los cuales la habían transmitido a los monarcas; pero ante la ausencia o cautividad de éstos, los pueblos quedaban libres para reformar sus instituciones políticas. Afirmaba que por eso el Congreso de Chilpancingo se había reunido, para conservar la religión, vengar los ultrajes y desafueros que habían sufrido los pueblos y para librarse de las garras de la tiranía y "el francmasonismo", que los iban a absorber para siempre. ${ }^{61}$

mexicana y la prensa insurgente, México, INEHRM, 1985, p. 65. Semanario patriótico americano, 10 de enero de 1813, núm. 26, 231, en Manuel Calvillo (coord.), La república federal mexicana. Gestación y Nacimiento, México, Secretaría de Gobernación y de Hacienda y Crédito Público/Biblioteca Nacional de México/Condumex, 1974; vol. 5 a cargo de Tarsicio García Díaz, La prensa insurgente, tomo 1, p. 561.

${ }^{58}$ Semanario patriótico americano, 27 de septiembre de 1812, núm. 11, p. 106; en Calvillo, La república...; vol. 5, p. 436.

${ }^{59}$ Esta idea la ha desarrollado con mayor amplitud Alfredo Ávila en "Cuando se canonizó...”, en prensa.

${ }^{60}$ Correo americano del Sur, 1 de abril de 1813, núm. vI, p. 46; en Calvillo, La república..., Vol. 6, a cargo de Tarsicio García Díaz, La prensa insurgente, tomo 2, p. 80.

${ }^{61}$ Alocución del señor Morelos en la sesión del congreso, del 14 de septiembre de 1813, en Hernández y Dávalos, Colección de documentos..., documento núm. 242, 2006. 
Como habrá podido verse, las ideas de la literatura antimasónica estaban presentes tanto entre los insurgentes como entre los realistas, de modo que los mismos elementos podían emplearse para apoyar posturas diferentes y hasta contrarias. Los planteamientos que relacionaban a la masonería con Napoleón también permitían identificarla con los liberales peninsulares o con los insurgentes, pues lo que se encontraba a la base de esa lectura era la convicción de que la masonería tendía a la disolución del orden establecido por Dios para el universo, temor que, al menos en los primeros ańos, compartían los insurgentes, los realistas y los escritores peninsulares catalogados como serviles. El problema era, para todos estos autores, que la masonería difundía un lenguaje subversivo, que lo mismo podía alimentar los movimientos insurgentes -como pensaban los realistas-, que fundamentar las medidas anticlericales de las cortes gaditanas y sostener al gobierno napoleónico -como suponían los publicistas serviles o insurgentes-.

El problema en el fondo de esta coincidencia parece ser el temor que despertaba el advenimiento de un orden político distinto, que iba acompańado de conceptos nuevos y no tan nuevos, pero cuyos contenidos semánticos no estaban muy claros, por lo que podían sustentar numerosas posturas, muchas de las cuales implicaban profundas transformaciones en las estructuras política, social y espiritual, que por entonces estaban indisolublemente vinculadas. Esto implicaba el surgimiento de nuevos mecanismos y espacios de negociación política y de legitimidad, pero también la pérdida de fuerza de otros que hasta entonces habían sostenido el funcionamiento del cuerpo político; esa pérdida atemorizaba a muy distintos sectores de la sociedad hispana de ambos hemisferios.

\section{EPÍLOGo}

En 1814, Fernando VII abolió la Constitución de Cádiz y las libertades que había consignado, entre ellas la libertad de imprenta, en virtud de lo cual el debate público se redujo notablemente y el tema masónico dejó de estar en el centro de las discusiones, que por lo demás fueron bastante escasas durante el sexenio absolutista. 
Tras el fusilamiento de Morelos, a finales de 1815, la insurgencia perdió fuerza, y quedó reducida a una serie de guerrillas. En 1817 llegó a Nueva Espańa la expedición de Francisco Xavier Mina, para la cual tuvo una importante participación la Sociedad de Caballeros Racionales de Londres y en la que intervinieron destacados personajes de la política novohispana, como Servando Teresa de Mier y la familia Fagoaga. Quizá este movimiento haya sido el más cercano al ideario político que se consideraba masónico, en tanto que estaba cimentado en la lucha contra el despotismo, del cual Mina y sus hombres consideraban que había hecho gala Fernando VII al disolver las Cortes y abolir la Constitución. Pese a que la historiografía ha consignado la pertenencia de Mina a la masonería, en sus proclamas -que fueron de los pocos impresos no realistas que circularon en esos ańos- no abordaba el tema masónico, ni vinculaba los principios que defendía con la pertenencia a esa asociación. Su silencio a este respecto bien puede haber sido resultado del temor que despertaban las renovadas prohibiciones contra la francmasonería o de las consecuencias negativas que podría acarrearle el reconocer su calidad de masón, por la negativa imagen pública que tenía dicha fraternidad en ambos lados del Atlántico.

Según Lucas Alamán, Mina esperaba que sus vínculos masónicos le permitieran atraerse la voluntad de las tropas expedicionarias que se encontraban por entonces en la Nueva Espańa, entre las que asegura había numerosos francmasones. Sin embargo, en la proclama que el navarro les dirigió tampoco hizo alusión alguna a tal hermandad. Esa presencia de masones entre los expedicionarios también ha sido consignada por la historiografía, pero no hay elementos para confirmarla pues no se ha localizado documentación al respecto, y en el momento en que estos hechos estaban sucediendo el tema prácticamente no fue abordado en los papeles públicos. Si los insurgentes tenían conocimiento de que entre las tropas realistas había masones, seguramente hubieran deseado explotar el asunto en sus impresos para seguir deslegitimando a sus oponentes, pero la falta de libertad de imprenta debe habérselos impedido.

La aventura de Mina fue efímera y fracasó, según Luis Villoro, porque los contenidos ideológicos de su lucha no coincidían con la 
concepción popular de la insurrección novohispana, pues los insurgentes no peleaban a favor de la Constitución que Mina defendía. ${ }^{62}$ Así, el expedicionario navarro fue fusilado a finales de 1817.

Otra consecuencia de la expedición, en la que venía Servando Teresa de Mier, fue el proceso que se le siguió a éste por francmasonería y por estar involucrado en los movimientos sediciosos. En su declaración, Mier aseguró que la Sociedad de Caballeros Racionales no era masónica, y tampoco era contraria a la religión, ni a la moral, ni al rey. Aseguraba que él no quería ser masón, pues serlo estaba prohibido por el papa y porque creía que, o la masonería era cosa mala, o si era buena no era preciso el secreto bajo juramentos tan execrables; además, sostenía que las sociedades secretas eran sospechosas y sólo propias para producir un tirano. ${ }^{63}$

No es fácil saber cuál era realmente la postura de fray Servando respecto a la masonería, pues es evidente que sus declaraciones estaban sesgadas por el hecho de estar frente al tribunal del Santo Oficio. Sin embargo, sus dichos y la persecución de las autoridades permiten constatar que el hecho de que ser masón siguiera siendo un delito y una herejía contribuía de forma notable a que la imagen pública de la masonería siguiera siendo predominantemente negativa. Es posible que, al menos en estos primeros momentos, a Mier la masonería le haya parecido un mecanismo útil para ayudar a obtener la independencia de Nueva Espańa, e incluso es factible que haya coincidido con algunos de los principios de la orden y con el ideario político que se consideraba masónico, pero las circunstancias no le permitieron sostenerlo abiertamente.

El juicio seguido a Servando Teresa de Mier no tuvo resonancia en los papeles públicos, pues como se mencionó arriba, fueron muy pocos los impresos de estos años, y los juicios de la Inquisición eran secretos. Por lo tanto, la presencia del tema masónico en los papeles públicos fue prácticamente nula en este periodo.

${ }^{62}$ Luis Villoro, El proceso..., 1999, 122-123.

${ }^{63}$ Declaraciones de Fray Servando Mier, Décima séptima declaración, 21 de noviembre de 1817, en Hernández y Dávalos, 2009, doc. 960. 
En los últimos años antes de que se consumara la independencia, las posturas políticas se fueron pluralizando y poco a poco el pensamiento liberal fue ganando terreno, de modo que comenzaron a aumentar los partidarios de un régimen constitucional. En realidad, el Plan de Iguala, promovido por Agustín de Iturbide, mediante el cual se organizó la última etapa de la independencia, concilió intereses muy disímiles, que se unieron temporalmente en torno al fin común de separarse de Espańa. ${ }^{64}$ En ese momento comenzaron a tener mayor presencia en la lid pública algunos personajes que la historiografía ha consignado como masones, como José María Fagoaga y Jacobo de Villaurrutia, quienes apoyaron la independencia y abrazaron algunos de los principios liberales del ideario político que se consideraba masónico; pero por el momento no hicieron pública su pertenencia a la orden. Fue hasta el restablecimiento de la libertad de imprenta que el tema masónico comenzó a abordarse de nuevo en los papeles públicos, y ya con características distintas, que respondían a nuevas circunstancias y condiciones políticas, así como a la adopción, por una parte más amplia de la población novohispana, de algunos de los planteamientos de las nuevas doctrinas políticas, como el respeto a algunos derechos individuales, la soberanía del pueblo y la lucha contra el fanatismo.

Cuando se consumó la independencia y se estableció el imperio de Iturbide el tema masónico empezó a desempeñar un papel fundamental en el debate público mexicano. Primero cuando ciertos principios del liberalismo clásico fueron adoptados y defendidos por diversos publicistas y actores políticos en México, y más tarde cuando la pertenencia a distintos ritos masónicos se volvió parte esencial en la construcción de las identidades políticas de los grupos que contendían por el poder. Así, entre 1821 y 1830, la masonería se convirtió en un tema central, cuya discusión contribuyó a analizar, consolidar y modificar los fundamentos del nuevo sistema político mexicano.

${ }^{64}$ Alfredo Ávila, Para la libertad. Los republicanos en tiempos del imperio 1821-1823, México, unAm, 2004, 75. 


\section{Consideraciones FinAlES}

En Nueva España, durante la lucha por la independencia, no hubo en realidad un debate público acerca de la masonería, como sí lo hubo en Europa, sino que las ideas que se difundieron acerca de ella -de las cuales se tomaron las líneas argumentativas de que harían uso insurgentes y realistas- se heredaron de la metrópoli y, por lo mismo, estuvieron sesgadas, en prácticamente todos los ámbitos donde se tuvo conocimiento de su existencia, por el rechazo que generaba entre las autoridades temporales y espirituales.

El carácter religioso que tuvieron las primeras fases de la lucha por la independencia, el temor generalizado que se había desatado en Nueva Espańa en contra de los franceses y masones a raíz de la revolución, las ideas derivadas de la literatura antimasónica europea, el celo de las autoridades para impedir la circulación de obras apologéticas de la masonería, y las doctrinas teológico-políticas en que se inspiraban cabecillas del movimiento, como Hidalgo, determinaron la imagen pública que tuvo la masonería. En este sentido, la idea de que la masonería fue un elemento fundamental del proceso independentista parece resultado de un discurso construido por los opositores de la independencia y del gobierno gaditano, que se alimentó de la larga tradición negativa que acompañaba a la masonería casi desde su fundación, por virtud de la literatura antimasónica.

Pero esta investigación, además de llevar a esas conclusiones, permite acercarse a los lenguajes políticos, a la cultura política del periodo y a procesos que van más allá de la importancia de la masonería en la independencia. En estos años, el tema masónico fue relevante pues se empleó como motivo para poner en cuestionamiento y en acción los principios de las nuevas y viejas doctrinas políticas. En los textos revisados puede constatarse que, mientras discutían sobre la masonería, sus autores iban expresando cuál era la cultura política desde la que escribían y actuaban, cuáles eran los principios, ideales y proyectos que se debatían, y cómo se ajustaban a las condiciones que imponía el nuevo orden político. Así, no sólo se observa el bagaje que compartían insurgentes y realistas, sino también se muestra -como ya han señalado Connaughton, Hamill 
y Ávila, entre otros ${ }^{65}$ - que algunos autores de la época, por más tradicionalistas que fueran, se vieron precisados a acudir al nuevo espacio de legitimidad que comenzaba a consolidarse: el debate público.

Asimismo, en numerosos casos los mismos papeles públicos que expresaban la lectura negativa sobre la masonería fueron difundiendo el lenguaje liberal y revolucionario atribuido a los masones, que tanto temor causaba a lectores en principio tradicionalistas, como los suscriptores de los Desengaños de Fernández de San Salvador. Con ello, a pesar de sus autores, se contribuyó no sólo a la apertura de los espacios públicos y al inicio de la formación de la opinión pública (pues comenzaba a apelarse a la opinión para legitimar las posturas políticas), sino también a que el nuevo lenguaje comenzara a ser aprehendido por otros sectores de la sociedad y a que paulatinamente su adopción incidiera en las transformaciones del modo de concebir la sociedad.

Finalmente, es preciso destacar que la forma en que los publicistas expresaban sus ideas acerca de la masonería también es una expresión de la cultura política desde la cual escribían, y en ese sentido, es de suma importancia destacar que sus textos son hechos históricos en sí mismos. Por una parte, porque lo que dijeron, cómo lo dijeron y los medios a través de los cuales lo dijeron sólo fueron posibles en sus circunstancias concretas; es decir, el pensamiento político que expresaban es resultado de sus condiciones históricas de formulación, y como tal amerita ser estudiado. Por otra, porque las publicaciones mediante las cuales daban a conocer y sometían a discusión sus planteamientos estaban elaboradas con una intención determinada, buscaban generar reacciones, pretendían poner en acción los principios en los cuales se basaban, y de hecho incidían directamente en el acontecer político y en la cultura política. ${ }^{66}$

${ }^{65}$ Brian Connaughton, Ideología y sociedad en Guadalajara (1788-1853), México, Consejo Nacional para la Cultura y las Artes, 1992. Hugh M. Hamill, The Hidalgo..., 1966 y "The Rector to the Rescue: Royalist Pamphleteers in the Defense of Mexico, 1808-1821", en Roderic A. Camp, Charles Hale y Josefina Zoraida Vázquez, eds., Los intelectuales y el poder en México, México, El Colegio de México/ucla Latin American Center Publications, 1991, 49-61. Alfredo Ávila, “Cuando se canonizó...”, en prensa.

${ }^{66}$ Para un análisis sobre esta forma de acercarse a los textos de intervención política véase Lucien Jaume, "El pensamiento en acción: por otra historia de las ideas políticas", Ayer, núm. 53, 2004, 112. 


\section{REFERENCIAS}

Archivos consultados

Archivo General de la Nación. Fondos Criminal, Indiferente de Guerra, Inquisición.

Biblioteca Nacional. Colección Lafragua

Hemeroteca Nacional. Fondo Antiguo

Hemerografia

Correo Americano del Sur

Ilustrador Nacional

Semanario Patriótico Americano

\section{Manuscritos e impresos}

Alocución del señor Morelos en la sesión del congreso, del 14 de septiembre de 1813, sin pie de imprenta.

Bula del soberano pontifice contra los fracmazones, México, Imprenta Americana de D. José María Betancourt, 1822.

Barruel, Agustín, Conspiración de los sofistas de la impiedad contra la religión y el estado, o, Memorias para servir a la historia del jacobinismo, Madrid, Imprenta de Collado, 1814, 4 vol.

Bustamante, Carlos María de, Suplemento de la historia de los tres siglos de México, Carta Séptima, en Boletín del Archivo General de la Nación, tomo viI, núm. 2, abril-junio 1936, 161-163.

Declaraciones de Fray Servando Mier, en Juan E. Hernández y Dávalos, Colección de documentos para la historia de la guerra de independencia de México, bajo la dirección de Alfredo Âvila y Virginia Guedea, en www.pim.unam.mx, México, unAM, 2009.

Feijoo, Jerónimo de, Cartas eruditas y curiosas, 1774. Edición digital en: http://www.filosofia.org/bjf/bjfc416.htm

Fernández de San Salvador, Agustín Pomposo, Desengaños que a los insurgentes de N. España, seducidos por los fracmazones agentes de Napoleón dirige la verdad de la religión católica y la experiencia, México, Oficina de D. Mariano de Zúniga y Ontiveros, 1812. , Convite a los verdaderos amantes de la religión católica y de la patria, México, Oficina de Ontiveros, 1812. 
López, Simón, Despertador Christiano-Politico, Murcia, reimpreso en México por Juan López de Cancelada, 1809.

Proceso del francmasón Pedro Tournon, juzgado por la Inquisición de Madrid, el año de 1757, México, Imprenta en la oficina de D. J. M. B. y socios, 1822.

Secretaría de la M $\therefore$ R $\therefore$ G $\therefore$ L $\therefore$ N $\therefore$ M $\therefore$, [Circular núm. 25 de la Gran Logia Nacional Mexicana sobre el impreso titulado Gracias singulares del ciudadano José María Tornel, dictaminando que no ha lugar a formación de causa contra Tornel], México, 4 de julio de 1828.

San Bartolomé, José de, El duelo de la inquisición o pésame que un filósofo rancio de la América Septentrional da a sus amados compatriotas los verdaderos españoles por la extinción de tan santo y utilisimo tribunal, Madrid, Impreso por Don Francisco Martínez Dávila, 1814.

VÉLEz, Rafael, Preservativo contra la irreligión, o los planes de la falsa filosofía contra la religión y el estado, Reimpreso en México en la oficina de dońa María Fernández de Jáuregui, 1813.

Ximeno, José, Contestación de fray Josef Jimeno, del colegio de cruciferos de Querétaro, al manifiesto del señor Hidalgo, sin pie de imprenta, 1811.

, La verdadera felicidad, libertad e independencia de las naciones, México, Impreso en casa de Arizpe, 1813.

\section{Bibliografía}

Alamán, Lucas, Historia de Méjico, desde los primeros movimientos que prepararon su independencia en el año de 1808 hasta la época presente, México, Libros del Bachiller Sansón Carrasco, 1986.

Ávila, Alfredo, "Cuando se canonizó la rebelión. Conservadores y serviles en Nueva España”, en Érika Pani, coord., Historia, conservadurismos y derechas en México, México, FCE, en prensa.

, Para la libertad. Los republicanos en tiempos del imperio, 1821-1823 (Serie Historia Moderna y Contemporánea/41), UNAM (Instituto de Investigaciones Históricas), 2004, 346 p.

, "Interpretaciones recientes en la historia del pensamiento de la emancipación" en Alfredo Ávila y Virginia Guedea, coords., 
La independencia de México, temas e interpretaciones recientes, México, unam/IIH, 2007, 17-39.

Ávila, Alfredo y Virginia GuedeA, La independencia de México, temas e interpretaciones recientes, México, UNAM/IIH, 2007.

BAstian, Jean Pierre, "Una ausencia notoria: la francmasonería en la historiografía mexicanista”, Historia Mexicana, vol. XLVI, núm. 3, enero-marzo 1995, 439-460.

Berruezo, María Teresa, "La propaganda independentista de la logia mirandina en Londres”, en José A. Ferrer Benimeli, coord., Masonería Española y América, Zaragoza, Centro de Estudios Históricos de la Masonería Española, 1993, 95-113.

Brading, David A., Church and State in Bourbon México. The diocese of Michoacán, 1749-1810, Cambridge, Cambridge University Press, 1994.

Calvillo, Manuel, coord., La república federal mexicana. Gestación y nacimiento, México, Secretaría de Gobernación y de Hacienda y Crédito Público, Biblioteca Nacional de México, Condumex, 1974; vol. 5 a cargo de Tarsicio García Díaz, La prensa insurgente.

Canal, Jordi, El Carlismo: dos siglos de contrarrevolución en España, Madrid, Alianza, 2000.

Casa Madrid Mata, Octavio, Los orígenes de la Francmasonería en México, México, Academia de Historia de la Masonería, 2003.

Cochin, Agustin, Les Sociétés de Pensée et la Démocratie. Etudes Histoire Révolutionnaire, París, Plon-Nourrit Imprimeurs, 1921.

Connaunghton, Brian F., Ideología y sociedad en Guadalajara (1788-1853), México, Consejo Nacional para la Cultura y las Artes, 1992.

Cuevas, Mariano, Historia de la Iglesia en México, México, Porrúa, 6a ed., 1992.

, Historia de la nación Mexicana, México, Talleres tipográficos modelo, 1940.

Del Arenal Fenochio, Jaime, Un modo de ser libres, México, El Colegio de Michoacán, 2002.

, "Modernidad, mito y religiosidad en el nacimiento de México" en Jaime E. Rodríguez, The Independence of Mexico and 
the Creation of the New Nation, Los Ángeles, University of California, Latin American Center Publicatiosn, México, Chicano Program, 1989, 237-246.

Ferrer B, José A., Masonería e Inquisición en Latinoamérica durante el siglo XVIII, Caracas, Universidad Católica Andrés Bello/Instituto de Investigaciones Históricas, 1973.

, Bibliografía de la masonería, Madrid, Fundación Universitaria Espańola, 1978.

La masonería española en el siglo XVIII, España, Siglo XXI de España, 1986.

, "Las Cortes de Cádiz, América y la masonería", Cuadernos Hispanoamericanos, núm. 460, octubre de 1988, 7-34.

, coord., Masonería, politica y sociedad, III Symposium de Metodología Aplicada a la Historia de la Masonería Española, Córdoba, 15-20 de junio de 1987, España, Centro de Estudios Históricos de la Masonería Española, 1989.

, coord., Masonería española y América, Zaragoza, Centro de

Estudios Históricos de la Masonería Española, 1993. , La masonería española, Madrid, Istmo, 1996.

, "El discurso masónico y la Inquisición en el paso del siglo XVIII al XIx", Revista de la Inquisición, vol. 7, 1998.

FraHm, Sara A, "La cruz y el compás: compromiso y conflicto", Secuencia, núm. 22, México, Instituto Mora, 1992.

Furet, Françoise, Pensar la revolución francesa, Madrid, Petrel, 1980.

Gandía, Enrique de, "La vida secreta de San Martín", Todo es Historia, núm. 16, agosto de 1968, 8-19.

Grand Orient de France, "La evolución [de la francmasonería] del siglo xIx y de la primera mitad del siglo xx", en www.godf. org/foreign/es/histoire_es_02c.html.

GuedeA, Virginia, «Las sociedades secretas durante el movimiento de independencia”, en Jaime E. Rodríguez, ed., The Independence of Mexico and the Creation of the New Nation, Los Angeles, University of California, Latin American Center Publications, Mexico, Chicano Program, 1989, 45-62.

, "Una nueva forma de organización política: la sociedad se- 
creta de Jalapa 1812", en Amaya Garrita, ed., Un hombre entre Europa y América. Homenaje a Juan Antonio Ortega y Medina, México, Instituto de Investigaciones Históricas, UnAM, 1993, 185-208.

, "La historia política sobre el proceso de la independencia", en Alfredo Ávila y Virginia Guedea, coords., La independencia de México, temas e interpretaciones recientes, México, UNAM/IIH, 2007, 41-64.

Guzmán, José R., "Fray Servando Teresa de Mier y la sociedad Lautaro", Anales del Instituto Nacional de Antropología e Historia, $7^{\mathrm{a}}$ época, México, 1967-1968, 257-288.

Hamill, Hugh M., The Hidalgo Revolt. Prelude to Mexican Independence. Gainesville, University of Florida Press, 1966.

"The Rector to the Rescue: Royalist Pamphleteers in the Defense of Mexico, 1808-1821", en Roderic A. Camp, Charles Hale y Josefina Zoraida Vázquez, eds., Los intelectuales y el poder en México, México, El Colegio de México, ucla Latin American Center Publications, pp. 49-61.

Hernández Y Dávalos, Juan E., Colección de documentos para la historia de la guerra de independencia de México, edición bajo la dirección de Alfredo Ávila, y Virginia Guedea, en www.pim. unam.mx, México, unAM, 2009.

Herrejón Peredo, Carlos, Hidalgo. Razones de la insurgencia y biografía documental, México, sEP, 1987.

, "La revolución francesa en sermones y otros testimonios de México 1791-1823", en Solange Alberro, Alicia Hernández Chávez y Elías Trabulse, coords., La revolución francesa en México, México, El Colegio de México, Centro de Estudios Mexicanos y Centroamericanos, 1992.

Historia general de México, Obra preparada por el Centro de Estudios Históricos, Versión 2000, México, El Colegio de México, Centro de Estudios Históricos, 2000.

Jaume, Lucien, "El pensamiento en acción: por otra historia de las ideas políticas”, Ayer, núm. 53, 2004, 109-130.

Jiménez Codinach, Guadalupe, La Gran Bretaña y la independencia de México, México, FCE, 1991. 
Landavazo, Marco Antonio, La máscara de Fernando VII. Discurso e imaginario monárquico en una época de crisis. Nueva España, 1808-1822, México, El Colegio de México, Universidad Michoacana de San Nicolás de Hidalgo, El Colegio de Michoacán, 2001.

Martínez Zaldúa, Ramón, Historia de la masonería en Hispanoamérica, México, Costa-amic, 1967.

Mateos, José María, Historia de la masonería en México, facsimilar de la edición de 1884, México, Herbasa, 2003.

Mayer, Alicia, Lutero en el Paraíso. La Nueva España en el espejo del reformador alemán, México, FCE, IIH, UNAM, 2008.

Mora, José María L., Obras sueltas, México, Porrúa, 1963.

Oсамто, Emilio, "Inglaterra, la masonería y la independencia de América", Todo es Historia, núm. 463, febrero de 2006, 6-21.

Pascual, Pedro, "Ausencia de periódicos y libros masónicos en la Independencia de América”, AIH, Actas XII, 1995, 194-202.

Ramírez Valdez, Miguel, El Rito Primitivo en México, en: http:// unicorniod64.googlepages.com/018elritoprimitivoenmxico. pdf.

RANGel, Nicolás, La vida colonial. Los precursores ideológicos de la guerra de independencia. La masonería en México, siglo XVIII, Publicaciones del Archivo General de la Nación, xxi, México, Talleres Gráficos de la Nación, 1932.

Rojas, Rafael, La escritura de la independencia. El surgimiento de la opinión pública en México, México, Taurus, CIDE, 2003.

Schmidt, Peer, "Una vieja élite en un nuevo marco político: El Clero Mexicano y el inicio del conservadurismo en la época de las Revoluciones Atlánticas (1776-1821)”, en Sandra Kuntz Ficker y Horst Pietschmann, México y la economía atlántica (siglos XVIIIXX), México, El Colegio de México, 2006, 67-105.

Terán, Marta, "La Virgen de Guadalupe contra Napoleón Bonaparte. La defensa de la religión en el obispado de Michoacán entre 1793 y 1814", Estudios de Historia Novohispana, vol. 19, 1999, 91-129.

Tornel y Mendivil, José María, Breve reseña histórica de los acontecimientos más notables de la nación mexicana, México, INEHRM, 
1985, edición facsimilar de la primera edición de 1852, en la imprenta de Cumplido.

Torre, Ana Laura de la, La expedición de Xavier Mina a la Nueva España: una utopia liberal imperial, Tesis de maestría, Instituto Mora, 1996.

Torres Puga, Gabriel, "Centinela mexicano contra francmasones. Un enredo detectivesco del licenciado Borunda en las causas criminales contra franceses de 1794", Estudios de Historia Moderna y Contemporánea, vol. 33, 2005.

Uribe-Uran, Víctor M., "The Birth of a Public Sphere in Latin America during the Age of Revolution", Comparative Studies in Society and History, 42, 2, abril 2000, 425-457.

VÁZqueZ, Josefina Zoraida, "Liberales y conservadores en México: diferencias y similitudes", EIAL, Estudios Interdisciplinarios de América Latina y el Caribe, vol. 8, núm. 1, enero-junio 1997. www.tau.ac.il/eial/VIII_1/

Verges, J. M. Miquel I., La independencia mexicana y la prensa insurgente, México INEHRM, 1985.

VIdal, César, "Los protocolos de los sabios de Sión”, Ideas. Libertad digital, Madrid, 2002. Revista electrónica en: http://revista.libertaddigital.com/articulo.php/1275325957

, Los masones. La sociedad secreta más influyente de la historia, México, Planeta, 2005.

VILlORO, Luis, El proceso ideológico de la revolución de independencia, México, CONACulTa, 1999.

, "La revolución de independencia", en Historia General de México, México, El Colegio de México, 2000, 491-523.

, "Rousseau en la Independencia mexicana", Revista Casa del Tiempo, núm. 80, septiembre, 2005.

Zalce y Rodríguez, Luis J., Apuntes para la historia de la masonería en México, México, Herbasa, 1950.

FECHA DE RECEPCIÓN DEL ARTÍCULO: 20 de mayo de 2008

FECHA DE ACEPTACIÓN Y RECEPCIÓN DE LA VERSIÓN FINAL: 7 de octubre de 2009 